\title{
Repeated Measurement of Fractional Exhaled Nitric Oxide Is Not Essential for Asthma Screening
}

\author{
Yang SY${ }^{1}$, Kim $\mathrm{YH}^{2}$, Byun $\mathrm{MK}^{1}$, Kim HJ${ }^{1}$, Ahn $\mathrm{CM}^{1}$, Kim SH${ }^{1}$, Lee $\mathrm{HS}^{3}$, Park $\mathrm{HJ}^{1,4}$ \\ 'Department of Internal Medicine, Gangnam Severance Hospital, Seoul, Korea \\ ${ }^{2}$ Department of Pediatrics, Gangnam Severance Hospital, Seoul, Korea \\ ${ }^{3}$ Biostatistics Collaboration Unit, Seoul, Korea \\ ${ }^{4}$ Department of Internal Medicine, Yong-in Severance Hospital and Yonsei University College of Medicine, Seoul, Korea
}

J Investig Allergol Clin Immunol 2018; Vol. 28(2): 98-105

doi: 10.18176/jiaci.0215

\begin{abstract}
Background: Older guidelines recommend that fractional exhaled nitric oxide (FeNO) should be checked more than twice during the same session to confirm an asthma diagnosis. Recent studies show the excellent reproducibility of FeNO measurements.

Objective: We aimed to determine whether repeated FeNO measurements during the same session are necessary for asthma screening. Methods: We retrospectively reviewed the electronic medical records of adult outpatients who visited the respiratory medicine department for diagnosis of asthma and assessed FeNO measurements obtained from June 2016 to July 2017.

Results: Of the 132 patients enrolled, 79 (59.8\%) were diagnosed with asthma. Repeated FeNO measurements taken during the same session showed high reproducibility (intraclass correlation coefficient $>0.9 ; P<.001$ ) and a strong correlation (Pearson coefficient $>0.9$; $P<.001)$, although reproducibility and correlation were slightly weaker in patients with low FeNO values. The value of repeated measurement was not significant; however, the second FeNO measurement was significantly higher than the first measurement in patients with the worst and best lung function. The predictive power of the first measurement of FeNO (sensitivity, 80.5\%; specificity, 85.1\%) was not inferior to the second (sensitivity, 76.6\%; specificity 85.1\%). The same was true of the geometric mean of the two.

Conclusion: Repeated FeNO measurement during the same session is not essential for asthma screening in cases where the first acceptable FeNO measurement is performed using the proper method.
\end{abstract}

Key words: Asthma. Fractional exhaled nitric oxide. Repeated measurements.

\section{Resumen}

Introducción: Aunque las guías más antiguas recomiendan que el óxido nítrico exhalado (FeNO) se determine más de dos veces en la misma sesión para el diagnóstico de asma, algunos estudios recientes han demostrado la excelente reproducibilidad de las mediciones de FeNO. Objetivo: Nuestro objetivo fue determinar si las mediciones repetidas de FeNO durante la misma sesión son necesarias para el cribado del asma.

Métodos: Revisamos retrospectivamente los registros médicos electrónicos de pacientes adultos ambulatorios que visitaron el departamento de neumología para confirmar un diagnóstico de asma durante los meses de junio de 2016 a julio de 2017, y se evaluaron las mediciones de FeNO obtenidas.

Resultados: De un total de 132 pacientes estudiados, 79 pacientes (59,8\%) fueron diagnosticados con asma. Las mediciones repetidas de FeNO tomadas durante la misma sesión mostraron una alta reproducibilidad (coeficiente de correlación intraclase $>0,9 ; p<0,001$ ) y una fuerte correlación (coeficiente de Pearson $>0,9 ; p<0,001$ ); sin embargo, la reproducibilidad y la correlación fueron ligeramente más débiles en sujetos con valores bajos de FeNO. El valor de la medición repetida no fue significativamente diferente entre sí en general; sin embargo, la segunda medición de FeNO fue significativamente más alta que la primera medición en sujetos con valores de la función pulmonar más bajos y más altos. El poder predictivo de FeNO para el diagnóstico de asma medido la primera vez (sensibilidad, 80,5\%; especificidad, $85,1 \%$ ) no fue inferior al medido la segunda vez (sensibilidad, 76,6\%; especificidad 85,1\%) o la media geométrica uniforme de los dos. Conclusión: La medición repetida de FeNO durante la misma sesión no es esencial para el cribado del asma en los casos en que la primera medición de FeNO es aceptable y se realiza con el método adecuado.

Palabras clave: Asma. Óxido nítrico exhalado fraccional. Mediciones repetidas. 


\section{Introduction}

Fractional exhaled nitric oxide (FeNO) reflects eosinophilic airway inflammation and is easily measured. The utility of FeNO was recently demonstrated for the diagnosis and monitoring of asthma [1,2]. However, specific patient characteristics and environmental factors are known to influence FeNO levels [3-6]. In addition, to obtain a reliable FeNO level, the operator must be sufficiently skilled to maintain a constant expiratory flow rate during the test. The 2005 American Thoracic Society (ATS)/European Respiratory Society (ERS) guidelines recommend performing FeNO measurements twice to obtain 2 values; the mean of the 2 values should then be used to interpret the test [7]. However, there has been no definite evidence to support this protocol. The reproducibility of FeNO measurements was recently shown to be excellent, and it was suggested that repeated FeNO measurements during the same session are unnecessary $[8,9]$. The utility of multiple FeNO measurements for diagnosis of asthma has never been studied.

This study aimed to determine whether repeated FeNO measurements obtained during the same session are necessary for confirmation of a diagnosis of asthma.

\section{Methods}

\section{Patients and Study Design}

We retrospectively reviewed the electronic medical records of adult outpatients aged $\geq 18$ years who visited the Respiratory Medicine Department of Gangnam Severance Hospital, Seoul, Korea. The patients were referred for measurement of FeNO between June 2016 and July 2017 to diagnose suspected asthma. To assess repeatability, a subset of the participants underwent paired FeNO measurements during the same visit. We examined the medical records of the patients enrolled and assessed baseline characteristics to define significant factors for FeNO level.

\section{FeNO Measurements}

FeNO was measured using a handheld device (NObreath FeNO Monitor, Bedfont Scientific Ltd) during scheduled study visits according to ATS/ERS guidelines [7]. The device uses an electrochemical sensor to detect exhaled NO levels and provides measurements from 5 ppb to $300 \mathrm{ppb}$ in whole numbers. We requested that all patients avoid eating, drinking, smoking, and performing strenuous exercise for 2 hours before the FeNO measurements to rule out bias. Moreover, the use of asthma drugs was forbidden unless the patient's physician had instructed otherwise.

Patients exhaled fully while seated, then inhaled over 2 to 3 seconds to total lung capacity through a filter, and finally exhaled with an upper airway pressure of 5 to $20 \mathrm{cmH} 2 \mathrm{O}$. Two successive FeNO measurements were performed with an interval of 4-5 minutes between them. All patients exhaled against an airflow resistor for 10 seconds at a flow rate of $50 \mathrm{~mL} / \mathrm{s}$, and the FeNO values were monitored on the screen of the device. Measurements were taken before performing spirometry. The detection limit of the NObreath device is $5 \mathrm{ppb}$.

\section{Lung Function Test and Bronchodilator Response Test}

Spirometry was carried out on the first study day after the FeNO measurements. Lung function tests were performed with a spirometer (Vmax, SensorMedics) in accordance with ATS/ERS recommendations [10]. Forced expiratory volume in $1 \mathrm{~s}\left(\mathrm{FEV}_{1}\right)$, forced vital capacity $(\mathrm{FVC})$, and the $\mathrm{FEV}_{1} / \mathrm{FVC}$ ratio were obtained from the best reproducible forced expiratory maneuvers. A significant improvement in lung function resulting from bronchodilator use was defined as an improvement in prebronchodilator $\mathrm{FEV}_{1}$ of $\geq 12 \%$ and $200 \mathrm{~mL}$ after administration of salbutamol $(200 \mu \mathrm{g})$.

\section{Methacholine Challenge Test}

The methacholine challenge test was carried out using the standard 5-breath dosimeter method recommended by the ATS [11]. Methacholine dilutions of $1,4,8$, and $16 \mathrm{mg} / \mathrm{mL}$ were used. Spirometry was performed 30 seconds and 90 seconds after each inhalation. The test was finished when the $\mathrm{FEV}_{1}$ value decreased by more than $20 \%$ from baseline. Positivity was defined as a provocative concentration $<16 \mathrm{mg} / \mathrm{mL}$ that resulted in a $20 \%$ decrease in $\mathrm{FEV}_{1}$.

\section{Asthma Diagnosis}

Asthma was diagnosed by clinicians based on the symptoms, physical examination, and the results of the bronchodilator test and methacholine test in all patients according to the Global Initiative for Asthma standard [12].

\section{Definition of a Large Gap and Positivity in FeNO Measurements}

The upper quartile of patients with a larger gap between the first and second individual measurement values formed the large gap group. Moreover, a large gap was defined as a $>17.5 \%$ difference in FeNO values between the 2 measurements. Although there are some concerns about the cut-off value for FeNO, we adopted $30 \mathrm{ppb}$ based on findings from previous studies, including a Korean study $[13,14]$.

\section{Statistics}

All data analyses were performed using SPSS (SPSS Inc). As the FeNO values appeared to be log-normally distributed, we used the geometric mean. The chi-square test and $t$ test were used to assess differences in characteristics between patients with and without a large gap. The intraclass correlation coefficient (ICC) and Pearson correlation were used to assess the reproducibility and correlation between the first and second FeNO measurements. The significance of the difference in FeNO values between the first and second measurements was assessed using the paired $t$ test. Agreement between FeNO positivity and a diagnosis of asthma diagnosis was calculated. Univariate and multivariate regression analyses showed that sex, age, height, weight, body mass index (BMI), pulmonary function variables, and asthma history were significantly associated with FeNO level. After adjustment for significant factors (absolute $\mathrm{FVC}$ and $\mathrm{FEV}_{1}$ ), the ability to predict asthma was based on a receiver operating 
characteristic analysis to obtain the area under the curve, the sensitivity and specificity of the first and second FeNO measurements, the geometric mean, the larger of the 2 values, and the smaller of the 2 values. A $P$ value less than .05 was considered statistically significant.

\section{Ethics}

This study was exempt from approval by the Institutional Review Board of the Gangnam Severance Hospital, Yonsei University Health System.

\section{Results}

\section{Clinical Characteristics of the Patients}

Of the 132 patients enrolled (mean age, 42.8 [16.0] years; men, $50.0 \%), 79(59.8 \%)$ were diagnosed with asthma. The geometric mean values of the first and second FeNO measurements were $32.5 \mathrm{ppb}$ and $33.4 \mathrm{ppb}$, respectively; there was no statistically significant difference between the 2 values (Table 1).

\section{Determinants of a Large Gap in FeNO Measurements}

When we used $17.5 \%$ as the threshold for a large gap between FeNO measurements, 33 patients $(25.0 \%)$ were classified as belonging to the large gap group. Sex, age, height, weight, and lung function were not significantly different between patients with and without a large gap. Patients with a large gap had significantly higher BMI values than those without a large gap $(P=.015)$. Asthma was significantly more prevalent in patients without a large gap $(66.7 \%)$ than in those with a large gap $(39.4 \% ; P=.005)$. Patients with large gaps showed significantly lower FeNO values than those without large gaps (Table 1).

\section{Reliability, Correlation, and Comparison of FeNO Measurements}

In general, repeated FeNO measurements showed high reproducibility $(\mathrm{ICC}>0.9 ; P<.001)$ and strong correlations (Pearson coefficient $>0.9 ; P<.001$ ); however, in patients with low FeNO levels $(<52.8 \mathrm{ppb})$, the values for reliability and correlation were slightly weaker (ICC, 0.772-0.886; Pearson coefficient, 0.681-0.774) (Table 2; Figure, A).

The first FeNO levels measured (32.5 [2.3] ppb) were not significantly different from the second FeNO levels (33.4 [2.3] ppb) (Figure, B). However, the second values were significantly higher than the first values in patients with the poorest lung function ( $44.36 \mathrm{ppb}$ vs $40.60 \mathrm{ppb}$ in patients with the lowest FVC values, $P=.024$ ) (Table 2). This trend was also observed in patients with the best lung function (30.74 ppb vs $28.79 \mathrm{ppb}$ in patients with the highest $\mathrm{FVC}$ values, $P=.004$; $34.34 \mathrm{ppb}$ vs $32.50 \mathrm{ppb}$ in patients with the highest $\mathrm{FEV}_{1}$ values, $P=.014)$.

\section{Predictability of FeNO Measurements for Asthma Diagnosis Using the Agreement Rate}

When FeNO positivity was defined as $\geq 30 \mathrm{ppb}$, the predictive power of the FeNO measurement for asthma was excellent. Overall, the first measured FeNO value was not inferior to the second measurement for prediction of asthma in all subgroups (total agreement rate, $79.5 \%$ vs $78.0 \%$ ). Moreover, the total agreement rate for asthma using the first value was not inferior to that using the numerical mean of the 2

Table 1. Clinical Characteristics, Lung Function Test, and Geometric Mean of FeNO According to Group

\begin{tabular}{|c|c|c|c|c|}
\hline Variables & $\begin{array}{c}\text { Total } \\
(\mathrm{N}=132)\end{array}$ & $\begin{array}{l}\text { Patients Without Large Gap } \\
\qquad(\mathrm{n}=99)\end{array}$ & $\begin{array}{l}\text { Patients With Large Gap }{ }^{\mathrm{a}} \\
\qquad(\mathrm{n}=33)\end{array}$ & $P$ Value \\
\hline Sex (Male) & $50.0 \%$ & $51.5 \%$ & $45.5 \%$ & .546 \\
\hline Age, y & $42.8(16.0)$ & $41.9(15.2)$ & $45.5(18.2)$ & .307 \\
\hline Height, cm & $165.7(9.2)$ & $166.5(9.4)$ & $163.1(7.9)$ & .079 \\
\hline Weight, $\mathrm{kg}$ & $66.6(13.1)$ & $66.1(14.0)$ & $67.9(10.1)$ & .535 \\
\hline BMI, $\mathrm{kg} / \mathrm{m}^{2}$ & $24.2(3.7)$ & $23.7(3.5)$ & $25.6(3.9)$ & $.015^{\mathrm{b}}$ \\
\hline Absolute FVC, L & $3.8(1.0)$ & $3.9(1.0)$ & $3.6(1.0)$ & .094 \\
\hline Predicted FVC, \% & $97.3(13.0)$ & $97.9(13.1)$ & $95.7(12.8)$ & .419 \\
\hline Absolute $\mathrm{FEV}_{1}, \mathrm{~L}$ & $3.0(0.8)$ & $3.0(0.8)$ & $2.8(0.9)$ & .226 \\
\hline Predicted $\mathrm{FEV}_{1}, \%$ & $99.1(16.3)$ & $99.1(16.2)$ & $99.1(16.8)$ & .998 \\
\hline Asthma & $59.8 \%$ & $66.7 \%$ & $39.4 \%$ & $.005^{\mathrm{b}}$ \\
\hline \multicolumn{5}{|c|}{ Geometric mean of FeNO, ppb } \\
\hline First measurement & $32.5(2.3)$ & $37.7(2.4)$ & $20.9(1.8)$ & $<.001^{\mathrm{b}}$ \\
\hline Second measurement & $33.4(2.3)$ & $38.5(2.4)$ & $21.8(1.8)$ & $.001^{\mathrm{b}}$ \\
\hline
\end{tabular}

Abbreviations: BMI, body mass index; FeNO, fractional exhaled nitric oxide; FEV ${ }_{1}$, forced expiratory volume in 1 second; FVC, forced vital capacity. ${ }^{a} \mathrm{~A}$ large gap was defined as a $>17.5 \%$ difference in FeNO between the first and second measurements.

bSignificant factors (independent samples $t$-test). 
A

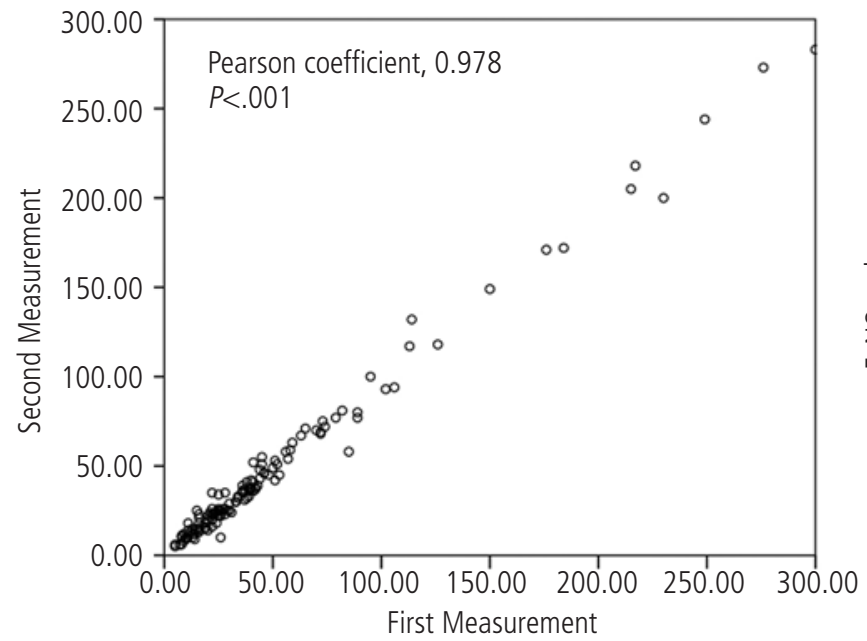

B

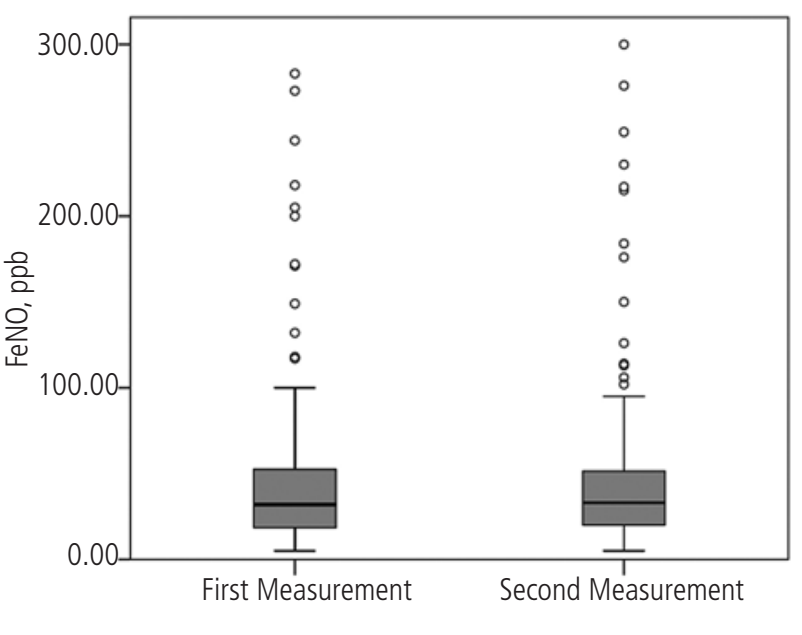

Figure. Correlation (A) and comparison (B) between the first and second FeNO measurements.

Table 2. Reliability, Correlation, and Comparison of FeNO Measurements

\begin{tabular}{|c|c|c|c|c|c|c|c|c|}
\hline \multirow[t]{2}{*}{ Variables } & \multirow{2}{*}{$\begin{array}{c}\text { Patients, } \\
\text { No. }\end{array}$} & \multicolumn{2}{|c|}{ Intraclass Correlation } & \multicolumn{2}{|c|}{ Pearson correlation } & \multicolumn{3}{|c|}{ Paired $t$ Test } \\
\hline & & Coefficient & $P$ Value & Coefficient & $P$ Value & $\begin{array}{c}\text { First } \\
\text { Measurement }\end{array}$ & $\begin{array}{c}\text { Second } \\
\text { Measurement }\end{array}$ & $P$ Value \\
\hline \multicolumn{9}{|l|}{ Sex } \\
\hline Male & 66 & 0.988 & $<.001$ & 0.977 & $<.001$ & 33.28 & 33.62 & .584 \\
\hline Female & 66 & 0.989 & $<.001$ & 0.979 & $<.001$ & 31.83 & 33.20 & .095 \\
\hline \multicolumn{9}{|l|}{ Age } \\
\hline$<65$ & 115 & 0.991 & $<.001$ & 0.983 & $<.001$ & 32.26 & 32.83 & .236 \\
\hline$\geq 65$ & 17 & 0.929 & $<.001$ & 0.952 & $<.001$ & 34.56 & 37.61 & .233 \\
\hline \multicolumn{9}{|l|}{ BMI } \\
\hline$<18.5$ & 6 & $>0.999$ & $<.001$ & 0.999 & $<.001$ & 40.17 & 39.75 & .428 \\
\hline $18.5-23$ & 40 & 0.986 & $<.001$ & 0.973 & $<.001$ & 28.17 & 29.32 & .222 \\
\hline $23-25$ & 29 & 0.989 & $<.001$ & 0.979 & $<.001$ & 34.85 & 36.34 & .210 \\
\hline$>25$ & 40 & 0.983 & $<.001$ & 0.967 & $<.001$ & 29.84 & 29.86 & .984 \\
\hline \multicolumn{9}{|l|}{ FVC } \\
\hline$<25 \%(<3.12 \mathrm{~L})$ & 31 & 0.989 & $<.001$ & 0.980 & $<.001$ & 40.60 & 44.36 & $.024^{\mathrm{a}}$ \\
\hline $25-50 \%(3.12-3.71 \mathrm{~L})$ & 32 & 0.988 & $<.001$ & 0.979 & $<.001$ & 31.11 & 30.42 & .507 \\
\hline $20-75 \%(3.71-4.65 \mathrm{~L})$ & 30 & 0.988 & $<.001$ & 0.976 & $<.001$ & 32.59 & 32.66 & .944 \\
\hline$>75 \%(>4.65 \mathrm{~L})$ & 31 & 0.995 & $<.001$ & 0.991 & $<.001$ & 28.79 & 30.74 & $.004^{\mathrm{a}}$ \\
\hline \multicolumn{9}{|l|}{$\mathrm{FEV}_{1}$} \\
\hline$<25 \%(<2.46 \mathrm{~L})$ & 31 & 0.989 & $<.001$ & 0.979 & $<.001$ & 48.59 & 52.00 & .088 \\
\hline $25-50 \%(2.46-3.00 \mathrm{~L})$ & 33 & 0.978 & $<.001$ & 0.958 & $<.001$ & 30.77 & 31.47 & .466 \\
\hline $20-75 \%(3.00-3.58 \mathrm{~L})$ & 29 & 0.989 & $<.001$ & 0.978 & $<.001$ & 23.97 & 23.60 & .642 \\
\hline$>75 \%(>3.58 \mathrm{~L})$ & 31 & 0.995 & $<.001$ & 0.991 & $<.001$ & 32.50 & 34.34 & $.014^{\mathrm{a}}$ \\
\hline \multicolumn{9}{|l|}{ FeNO } \\
\hline$<25 \%(<18.25)$ & 33 & 0.866 & $<.001$ & 0.774 & $<.001$ & 11.76 & 12.67 & $.117^{\mathrm{b}}$ \\
\hline $25-50 \%(18.25-32.00)$ & 34 & 0.772 & $<.001$ & 0.715 & $<.001$ & 24.40 & 24.74 & $.613^{\mathrm{b}}$ \\
\hline $50-75 \%(32.00-52.75)$ & 32 & 0.780 & $<.001$ & 0.681 & $<.001$ & 40.04 & 39.77 & $.783^{\mathrm{b}}$ \\
\hline$>75 \%(>52.75)$ & 33 & 0.991 & $<.001$ & 0.983 & $<.001$ & 99.14 & 101.38 & .204 \\
\hline Total & 132 & 0.989 & $<.001$ & 0.978 & $<.001$ & 32.55 & 33.40 & .094 \\
\hline
\end{tabular}

Abbreviations: BMI, body mass index; FeNO, fractional exhaled nitric oxide; $\mathrm{FEV}_{1}$, forced expiratory volume in 1 second; FVC, forced vital capacity.

a $P$ value $<.05$ obtained by paired t test.

bSlightly decreased reliability and correlation of FeNO between first and second measurements. 
Table 3. Agreement Rate Between FeNO Positivity ( $\geq 30 \mathrm{ppb})$ and Asthma

\begin{tabular}{|c|c|c|c|c|c|}
\hline Variables & $\begin{array}{c}\text { First } \\
\text { Measurement }\end{array}$ & $\begin{array}{c}\text { Second } \\
\text { Measurement }\end{array}$ & $\begin{array}{l}\text { Numerical } \\
\text { Mean of } \\
2 \text { Above }\end{array}$ & $\begin{array}{c}\text { Larger one } \\
\text { Selection } \\
\text { Between } 2 \text { Above }\end{array}$ & $\begin{array}{c}\text { Smaller one } \\
\text { Selection } \\
\text { Between } 2 \text { Above }\end{array}$ \\
\hline \multicolumn{6}{|l|}{ FVC } \\
\hline$<25 \%(<3.12 \mathrm{~L})$ & $87.1 \%{ }^{\mathrm{a}}$ & $83.9 \%$ & $87.1 \% \mathrm{o}^{\mathrm{a}}$ & $83.9 \%$ & $87.1 \%{ }^{\mathrm{a}}$ \\
\hline $25-50 \%(3.12-3.71 \mathrm{~L})$ & $84.4 \% \%^{\mathrm{a}}$ & $75.0 \%$ & $78.1 \%$ & $81.3 \%$ & $78.1 \%$ \\
\hline $20-75 \%(3.71-4.65 \mathrm{~L})$ & $70.0 \%$ & $73.3 \%{ }^{\mathrm{a}}$ & $70.0 \%$ & $73.3 \%{ }^{\mathrm{a}}$ & $70.0 \%$ \\
\hline$>75 \%(>4.65 \mathrm{~L})$ & $77.4 \% \%^{\mathrm{a}}$ & $77.4 \%{ }^{\mathrm{a}}$ & $77.4 \%{ }^{\mathrm{a}}$ & $77.4 \%{ }^{\mathrm{a}}$ & $77.4 \% \mathrm{a}^{\mathrm{a}}$ \\
\hline \multicolumn{5}{|l|}{$\mathrm{FEV}_{1}$} & $90.3 \%{ }^{\mathrm{a}}$ \\
\hline $25-50 \%(2.46-3.00 \mathrm{~L})$ & $75.8 \% \mathrm{a}^{\mathrm{a}}$ & $69.7 \%$ & $69.7 \%$ & $75.8 \% \mathrm{a}^{\mathrm{a}}$ & $69.7 \%$ \\
\hline $20-75 \%(3.00-3.58 \mathrm{~L})$ & $69.0 \%{ }^{\mathrm{a}}$ & $69.0 \%{ }^{\mathrm{a}}$ & $69.0 \%{ }^{\mathrm{a}}$ & $69.0 \%{ }^{\mathrm{a}}$ & $69.0 \%{ }^{\mathrm{a}}$ \\
\hline$>75 \%(>3.58 \mathrm{~L})$ & $83.9 \% \%^{\mathrm{a}}$ & $83.9 \%{ }^{\mathrm{a}}$ & $83.9 \%{ }^{\mathrm{a}}$ & $83.9 \%{ }^{\mathrm{a}}$ & $83.9 \% \%^{\mathrm{a}}$ \\
\hline \multicolumn{6}{|l|}{ FeNO, ppb } \\
\hline$<25 \%(<18.25)$ & $70.0 \% 0^{\mathrm{a}}$ & $70.0 \%{ }^{\mathrm{a}}$ & $70.0 \% \mathrm{a}$ & $70.0 \% 0^{\mathrm{a}}$ & $70.0 \% \mathrm{a}^{\mathrm{a}}$ \\
\hline $25-50 \%(18.25-32.00)$ & $70.6 \%{ }^{\mathrm{a}}$ & $67.6 \%$ & $70.6 \% \mathrm{a}$ & $67.6 \%$ & $70.6 \%{ }^{\mathrm{a}}$ \\
\hline $50-75 \%(32.00-52.75)$ & $81.3 \% \%^{\mathrm{a}}$ & $78.1 \%$ & $75.0 \%$ & $81.3 \% \%^{\mathrm{a}}$ & $78.1 \%$ \\
\hline$>75 \%(>52.75)$ & $97.0 \%{ }^{\mathrm{a}}$ & $97.0 \%{ }^{\mathrm{a}}$ & $97.0 \% \mathrm{a}$ & $97.0 \% 0^{\mathrm{a}}$ & $97.0 \% 0^{\mathrm{a}}$ \\
\hline Total & $79.5 \% \mathrm{a}^{\mathrm{a}}$ & $78.0 \%$ & $78.0 \%$ & $78.8 \%$ & $78.8 \%$ \\
\hline
\end{tabular}

Abbreviations: FeNO, fractional exhaled nitric oxide; FEV 1 , forced expiratory volume in 1 second; FVC, forced vital capacity.

a Highest agreement rate in the subgroup.

Table 4. Significant Factors in the Determination of the FeNO Value

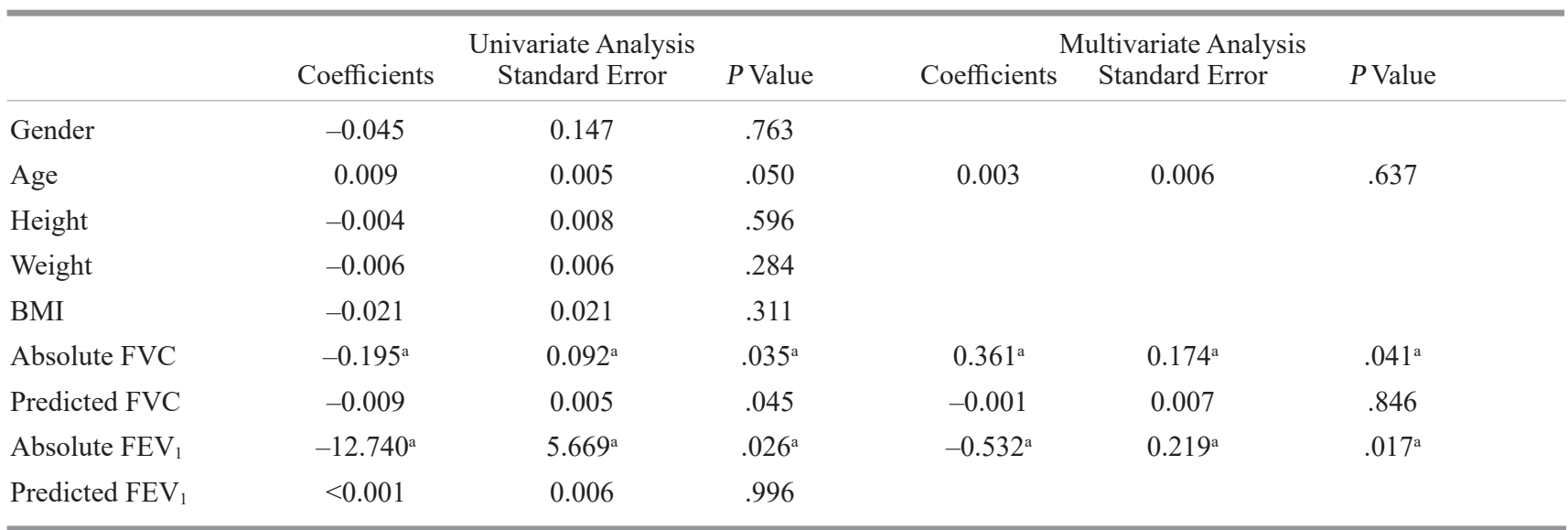

Abbreviations: BMI, body mass index; FeNO, fractional exhaled nitric oxide; FEV 1 , forced expiratory volume in 1 second; FVC, forced vital capacity.

asignificant factors for first FeNO measurement by multivariate linear regression analysis.

values, the larger of the first and second values, or the smaller of the first and second values (Table 3).

\section{Significant Determinants of the FeNO Value}

In the univariate linear regression analysis, sex, height, weight, and BMI were not significantly associated with the FeNO value. Age showed borderline significance $(P=.050)$. The absolute FVC, predicted FVC, and absolute $\mathrm{FEV}_{1}$ were significant factors for FeNO. The multivariate linear regression analysis showed that absolute FVC and absolute $\mathrm{FEV}_{1}$ were significantly associated with FeNO levels (Table 4). 
Table 5. Predictive Power of FeNO Measurements for Asthma Diagnosis Using a Multiple Regression Analysis ${ }^{\mathrm{a}}$

\begin{tabular}{lccccc}
\hline Variables & AUC & $95 \%$ CI & $P$ Value & Sensitivity & Specificity \\
\hline First measurement & $0.859^{\mathrm{a}}$ & $0.794-0.924^{\mathrm{a}}$ & $<.001^{\mathrm{a}}$ & $80.5 \%^{\mathrm{a}}$ & $85.1 \%^{\mathrm{a}}$ \\
Second measurement & 0.850 & $0.785-0.916$ & $<.001$ & $76.6 \%$ & $83.0 \%$ \\
Geometric mean of the previous two & 0.856 & $0.792-0.922$ & $<.001$ & $81.8 \%$ & $83.0 \%$ \\
Larger of the previous two & 0.857 & $0.793-0.922$ & $<.001$ & $79.2 \%$ & $85.1 \%$ \\
Smaller of the previous two & 0.859 & $0.795-0.923$ & $<.001$ & $81.8 \%$ & $80.9 \%$ \\
\hline
\end{tabular}

Abbreviations: AUC, area under the curve; FeNO, fractional exhaled nitric oxide.

aAll data are obtained by logistic regression after adjustment with absolute FVC and FEV 1 .

aest results among the variables.

\section{Predictive Power of FeNO Measurements for Diagnosis of Asthma Using a Multiple Regression Analysis}

After adjustment for lung function ( $\mathrm{FVC}$ and $\mathrm{FEV}_{1}$, based on the results of Table 4), the first FeNO value measured (AUC, 0.859; 95\%CI, 0.794-0.924; $P<.001$; sensitivity, $80.5 \%$; specificity, $85.1 \%$ with a cut-off of $30.0 \mathrm{ppb}$ ) was not significantly inferior to the second measured value (AUC, 0.850; 95\%CI, 0.785-0.916; $P<.001$; sensitivity, 76.6\%; specificity $85.1 \%$ with a cut-off of $29.0 \mathrm{ppb}$ ) (comparison of the ROC curves between the first FeNO value and second FeNO value, $P=.694)$, the geometric mean of the 2 measurements (AUC, 0.856; 95\%CI, 0.792-0.922; $P<.001$; sensitivity, 81.8\%; specificity, $83.0 \%$ ) (comparison of ROC curves between first FeNO value and geometric mean FeNO value, $P=.923$ ), the larger of the 2 values (AUC, $0.857 ; 95 \% \mathrm{CI}, 0.793-0.922$; $P<.001$; sensitivity, $79.2 \%$; specificity, $85.1 \%$ ) (comparison of ROC curves between first FeNO value and larger one, $P>.999$ ), or the smaller of the 2 values (AUC, $0.859 ; 95 \% \mathrm{CI}$, $0.795-0.923 ; P<.001$; sensitivity, $81.8 \%$; specificity, $80.9 \%$ ) (comparison of ROC curves between the first FeNO value and the smaller one, $P=.848$ ) (Table 5).

\section{Discussion}

We demonstrated that repeated FeNO measurements during the same session are not essential for diagnosis of asthma. The FeNO value was highly reproducible. In addition, the predictive value of the first FeNO measurement for asthma was not inferior to that measured the second time [15], the mean of the 2 values, the larger value, or the smaller value. Various institutions currently use the protocol recommended in the 2005 ATS/ERS guidelines, which state that the FeNO level should be measured twice and the mean value should be applied [7]. However, this recommendation is not supported by sufficient scientific evidence. Recent studies showed the excellent reproducibility and repeatability of FeNO measurements $[8,9]$. However, whether an asthma diagnosis can be made with only 1 FeNO measurement has not been studied. We suggest that the time and effort required to repeat the FeNO measurement could be saved, because a single FeNO measurement is sufficient to diagnose asthma.
Although we proved the excellent predictive value of a single FeNO measurement for diagnosis of asthma, some patients showed a significant gap in FeNO levels between the first and second measurements. Patients with normal-to-low FeNO values (in the bottom 75\%) showed modest agreement between the first and second FeNO values measured. The groups with the best lung function (in the top 25\%) and worst lung function (in the bottom 25\%) showed significantly higher FeNO values for the second measurement than for the first measurement. Therefore, we need to pay attention when measuring FeNO levels in these subgroups, where more than 1 measurement of the FeNO level may be necessary to obtain a definitive value. However, repeating the measurement may not affect the diagnosis of asthma.

Lung function played a significant role in the measurement of FeNO, whereas age, sex, and height did not. Several studies have demonstrated that age, sex, height, atopy, smoking status, and lung function can influence the level of FeNO [16]; however, no consensus has been reached $[3-6,10,13,17,18]$. We attempted to establish significant associations between these factors. Given that our study included a relatively small number of patients compared with previous studies, we could not be sure that age, sex, and height were not significantly associated. We reconfirmed that lung function was negatively correlated with FeNO values, consistent with previous data from a group in Korea [10]. A possible explanation for this finding could be that patients with severe eosinophilic inflammation might have high levels of FeNO and poor lung function [19].

Asthma is a chronic inflammatory airway disease that can be diagnosed and monitored using various tests [20]. The classic tests include lung function, a questionnaire, and induced sputum. Data were recently reported for FeNO and periostin, and interest in potential biomarkers such as $\mathrm{IgE}$, ykl-40, and CD93 has grown [21-24]. In the clinic, the FeNO level is easily measured before the performance of the lung function test. The utility of FeNO values has been widely demonstrated $[25,26]$; therefore, FeNO will be used more extensively in the future. Our study showed that repeated measurements of FeNO were unnecessary; consequently, the convenience and ease of a single FeNO measurement will enhance the utility of this approach.

Our study is subject to a series of limitations. First, it was performed at a single institution with a small number of 
patients. Our results should be confirmed in a larger study. Second, despite having a highly skilled and well-trained practitioner (which ensures excellent reproducibility), we are unsure whether a single FeNO measurement would be sufficient at institutions without skilled trainers. Third, we should interpret the results carefully, because we might have included patients with noneosinophilic asthma. Lastly, atopy, which is known to be significantly associated with FeNO level, was not included in the analysis because of missing data.

In conclusion, a single FeNO measurement was sufficient for asthma screening in cases where the first acceptable FeNO measurement was made using the appropriate method. A second measurement would be helpful in cases where the first acceptable measurement is much lower or higher than the clinician expected and in cases where lung function is extremely good or poor.

\section{Funding}

The authors declare that no funding was received for the present study.

\section{Conflicts of Interest}

The authors declare that they have no conflicts of interest.

\section{References}

1. Kim HB, Eckel SP, Kim JH, Gilliland FD. Exhaled NO: Determinants and Clinical Application in Children With Allergic Airway Disease. Allergy Asthma Immunol Res. 2016;8:12-21.

2. Feng JX, Lin Y, Lin J, He SS, Chen MF, Wu XM, et al. Relationship between Fractional Exhaled Nitric Oxide Level and Efficacy of Inhaled Corticosteroid in Asthma-COPD Overlap Syndrome Patients with Different Disease Severity. J Korean Med Sci. 2017;32:439-47.

3. Olin AC, Rosengren A, Thelle DS, Lissner L, Bake B, Toren $K$. Height, age, and atopy are associated with fraction of exhaled nitric oxide in a large adult general population sample. Chest. 2006;130:1319-25.

4. Kovesi T, Kulka R, Dales R. Exhaled nitric oxide concentration is affected by age, height, and race in healthy 9- to 12-year-old children. Chest. 2008;133:169-75.

5. Levesque MC, Hauswirth DW, Mervin-Blake S, Fernandez CA, Patch KB, Alexander KM, et al. Determinants of exhaled nitric oxide levels in healthy, nonsmoking African American adults. J Allergy Clin Immunol. 2008;121:396-402 e3.

6. Dressel H, de la Motte D, Reichert J, Ochmann U, Petru R, Angerer $P$, et al. Exhaled nitric oxide: independent effects of atopy, smoking, respiratory tract infection, gender and height. Respir Med. 2008;102:962-9.

7. American Thoracic Society, European Respiratory Society. ATS/ ERS recommendations for standardized procedures for the online and offline measurement of exhaled lower respiratory nitric oxide and nasal nitric oxide, 2005. Am J Respir Crit Care Med. 2005:171:912-30.

8. Kapande KM, McConaghy LA, Douglas I, McKenna S, Hughes $J$, McCance DR, et al. Comparative repeatability of two handheld fractional exhaled nitric oxide monitors. Pediatr Pulmonol. 2012;47:546-50.

9. Bohadana A, Michaely JP, Teculescu D, Wild P. Reproducibility of exhaled nitric oxide in smokers and non-smokers: relevance for longitudinal studies. BMC Pulm Med. 2008;8:4.

10. Jo EJ, Song WJ, Kim TW, Park HW, Chang YS, Kim TB, et al. Reference ranges and determinant factors for exhaled nitric oxide in a healthy korean elderly population. Allergy Asthma Immunol Res. 2014;6:504-10.

11. Crapo RO, Casaburi $R$, Coates $A L$, Enright PL, Hankinson $J L$, Irvin CG, et al. Guidelines for methacholine and exercise challenge testing-1999. This official statement of the American Thoracic Society was adopted by the ATS Board of Directors, July 1999. Am J Respir Crit Care Med. 2000;161:309-29.

12. GINA report, Global Strategy for Asthma Management and Prevention. http://www.ginasthma.com/guidelineitem.asp? 112\& 121\& intld1561. Accessed September 27, 2017.

13. Kim SH, Kim TH, Sohn JW, Yoon HJ, Shin DH, Park SS. Reference values and determinants of exhaled nitric oxide in healthy Korean adults. J Asthma. 2010;47:563-7.

14. Chatkin JM, Ansarin K, Silkoff PE, McClean P, Gutierrez C, Zamel $\mathrm{N}$ et al. Exhaled nitric oxide as a noninvasive assessment of chronic cough. Am J Respir Crit Care Med. 1999;159:18103.

15. Olaguibel JM, Parra A, Alvarez MJ, Quirce S, Lopez R. Measurements of fractional exhaled nitric oxide with 2 portable electrochemical sensors: a comparative study. J Investig Allergol Clin Immunol. 2011;21:322-3.

16. Alvarez-Puebla MJ, Olaguibel Rivera JM, Almudevar $E$, Echegoyen AA, de Esteban Chocarro B, Cambra K. Cutoff point for exhaled nitric oxide corresponding to $3 \%$ sputum eosinophils. J Investig Allergol Clin Immunol. 2015;25:10711.

17. Olivieri M, Talamini G, Corradi M, Perbellini L, Mutti A, Tantucci $C$, et al. Reference values for exhaled nitric oxide (reveno) study. Respir Res. 2006;7:94.

18. Travers J, Marsh S, Aldington S, Williams M, Shirtcliffe $P_{\text {, }}$ Pritchard $A$, et al. Reference ranges for exhaled nitric oxide derived from a random community survey of adults. Am J Respir Crit Care Med. 2007;176:238-42.

19. Amelink M, de Groot JC, de Nijs SB, Lutter R, Zwinderman $\mathrm{AH}$, Sterk PJ, et al. Severe adult-onset asthma: A distinct phenotype. J Allergy Clin Immunol. 2013;132:336-41.

20. Kim DK, Park YB, Oh YM, Jung KS, Yoo JH, Yoo KH, et al. Steering, Scientific Committee of Asthma Study G, Guideline Control Committee in The Korean Academy of T, Respiratory D. Korean Asthma Guideline 2014: Summary of Major Updates to the Korean Asthma Guideline 2014. Tuberc Respir Dis (Seoul). 2016;79:111-20.

21. Park HJ, Han H, Lee SC, Son YW, Sim DW, Park KH, et al. Soluble CD93 in Serum as a Marker of Allergic Inflammation. Yonsei Med J. 2017;58:598-603.

22. Song WJ, Sintobin I, Sohn KH, Kang MG, Park HK, Jo EJ, et al. Staphylococcal enterotoxin IgE sensitization in late-onset severe eosinophilic asthma in the elderly. Clin Exp Allergy. 2016;46:411-21.

23. Lee JH, Park KH, Park JW, Hong CS. YKL-40 in induced sputum after allergen bronchial provocation in atopic asthma. J Investig Allergol Clin Immunol. 2012;22:501-7. 
24. Jia G, Erickson RW, Choy DF, Mosesova S, Wu LC, Solberg OD, et al. Bronchoscopic Exploratory Research Study of Biomarkers in Corticosteroid-refractory Asthma Study G. Periostin is a systemic biomarker of eosinophilic airway inflammation in asthmatic patients. J Allergy Clin Immunol. 2012;130:647-54 e10.

25. Silkoff PE, Lent AM, Busacker AA, Katial RK, Balzar S, Strand M, et al. Exhaled nitric oxide identifies the persistent eosinophilic phenotype in severe refractory asthma. J Allergy Clin Immunol. 2005;116:1249-55.

26. Perez-de-Llano LA, Carballada F, Castro Anon O, Pizarro M, Golpe R, Baloira A, et al. Exhaled nitric oxide predicts control in patients with difficult-to-treat asthma. Eur Respir J. 2010;35:1221-7.
Manuscript received October 26, 2017; accepted for publication November 27, 2017.

\section{Hye Jung Park}

Department of Internal Medicine Gangnam Severance Hospital, Yonsei University College of Medicine

211, Eonju-ro, Gangnam-gu, Seoul, Republic of Korea, 06273

E-mail: craft7820@yuhs.ac 